\title{
Genetic risk factors associated with respiratory distress syndrome
}

\author{
Heui Seung Jo, MD, PhD \\ Department of Pediatrics, CHA Bundang Medical Center, CHA University, Seongnam, Korea
}

Respiratory distress syndrome (RDS) among preterm infants is typically due to a quantitative deficiency of pulmonary surfactant. Aside from the degree of prematurity, diverse environmental and genetic factors can affect the development of RDS. The variance of the risk of RDS in various races/ethnicities or monozygotic/dizygotic twins has suggested genetic influences on this disorder. So far, several specific mutations in genes encoding surfactant-associated molecules have confirmed this. Specific genetic variants contributing to the regulation of pulmonary development, its structure and function, or the inflammatory response could be candidate risk factors for the development of RDS. This review summarizes the background that suggests the genetic predisposition of RDS, the identified mutations, and candidate genetic polymorphisms of pulmonary surfactant proteins associated with RDS.

Key words: Newborn respiratory distress syndrome, Genetic polymorphism, Pulmonary surfactantassociated proteins

\section{Introduction}

Respiratory distress syndrome (RDS) is primarily due to the absence or transient deficiency of pulmonary surfactant (PS) ${ }^{1)}$. RDS is a major acute postnatal pulmonary disease that especially affects the preterm newborns, and is caused by an insufficiency of PS metabolism. The disorder can progress to respiratory failure. Although the incidence of RDS is inversely related to gestational age, prematurity alone does not determine the risk of developing the disorder ${ }^{2}$. Besides surfactant deficiency, diverse risk factors such as gender, ethnicity, and maternal diseases, which have interactions with one another, influence the development and the severity of $\operatorname{RDS}^{2-4)}$.

According to empirical observation and epidemiologic studies concerning racial differences and familial tendency, genetic disposition has been suggested for the risk of RDS ${ }^{5-}$ ${ }^{7)}$. In spite of antenatal steroid administration, postnatal surfactant therapy, and optimal ventilator care, not all infants of the same gestational period respond equally to treatments. From the intractable RDS cases, a few mutations, including genes encoding surfactant proteins $\mathrm{B}(\mathrm{SP}-\mathrm{B})^{8}{ }^{\text {) }}, \mathrm{SP}-\mathrm{C}^{9)}$, and the adenosine triphosphate-binding cassette transporter $\mathrm{A} 3$ $(\mathrm{ABCA} 3)^{10)}$, have been identified. Specific polymorphisms related to surfactant structure and function, pulmonary differentiation, and inflammatory response could be candidate genes for the development of $\operatorname{RDS}^{2,11-13)}$.

The present review summarizes the genetic aspect of RDS as follows. First, the histological and epidemiologic backgrounds that suggest the genetic predisposition for the development of RDS are introduced; these include studies on ethnic differences, and familial and twin studies. Then, the rare but revealed genetic causes of RDS are described, including the identified surfactant-associated mutations. Lastly, recent studies associating genetic
Corresponding author: Heui Seung Jo, MD, PhD Department of Pediatrics, CHA Bundang Medical Center, CHA University, 59 Yatap-ro, Bundang-gu, Seongnam 463-712, Korea

Tel: +82-31-780-5230

Fax: +82-31-780-5239

E-mail: joneona@cha.ac.kr

Received: 15 September, 2013

Accepted: 14 March, 2014
Copyright (C) 2014 by The Korean Pediatric Society

This is an open-access article distributed under the terms of the Creative Commons Attribution NonCommercial License (http://creativecommons.org/ licenses/by-nc/3.0/) which permits unrestricted noncommercial use, distribution, and reproduction in any medium, provided the original work is properly cited. 
polymorphisms for SP with RDS are shown.

\section{Historical studies that suggest a genetic predisposition to RDS}

\section{Ethnic/racial differences}

A higher rate of neonatal death and RDS has been reported for white newborn infants compared with black newborns, in spite of the relatively lower birth weights of the black infants ${ }^{5}$. The study of the US national mortality statistics for RDS in 1968-1973 showed a higher mortality rate in male infants than in female infants, and a lower incidence of fatal RDS in black preterm infants ${ }^{3)}$. On the other hand, there was a report that showed no racial differences in fetal lung maturation between the blacks and whites in the US; the influence of environmental factors, such as maternal body weight and smoking, for the development of RDS was suggested $^{14)}$. In spite of these few opposing results ${ }^{14)}$, regression analyses have shown that RDS occurs less frequently and less severely in black preterm infants, whereas white ethnicity is an independent risk factor of RDS in preterm and term infants ${ }^{15-17)}$.

To date, the underlying mechanisms related to the racial difference in the occurrence of RDS have not been definitively revealed. Olowe and Akinkugbe ${ }^{18)}$ suggested the earlier pulmonary maturation in Africans as being one of the mechanisms for the racial difference, based on the result of a higher amniotic fluid lecithin/sphingomyelin (L/S) ratio in African babies than in North American babies. Antenatal steroid treatment proved to be effective in non-Caucasians, whereas Caucasians showed little benefit from this intervention ${ }^{19)}$. Richardson and Torday ${ }^{20)}$ stratified the data by $\mathrm{L} / \mathrm{S}$ ratio to adjust for possible differences in maturational timing between races, and showed lower rates of RDS in the black infants at every level of the L/S ratio. They suggested an alternative hypothesis of qualitative differences in the surfactants between races, including differences of phospholipids and surfactant proteins, or anatomic differences in the alveolar size and structure. Genetic differences such as allelic variation may contribute to the protein structure and function ${ }^{2,12,21)}$.

\section{Family studies}

The increased risk of developing RDS with a history of previously affected infants has been suggested an important genetic or other familial tendency in its origin ${ }^{6,7)}$. There should be other considerations for the results analysis of the family studies; that is, the possibility of including populations with a genetic predisposition to preterm birth, or the confounding environmental effects, as well as genetic influences ${ }^{2,6)}$. Although most of the identified mutations of SP-B and $A B C A 3$ are family specific ${ }^{22,23)}$, and differences of SPs or maternal hormonal factor were suggested ${ }^{6}$, the integrative precise mechanism to explain these results is not clear.

\section{Twin studies}

Genetic predisposition in the susceptibility to RDS has been suggested by twin studies. The concordance difference of RDS between monozygotic (MZ) and dizygotic (DZ) twins (viz., the higher frequency of RDS in MZ than in DZ twins) supports the genetic contribution to $\operatorname{RDS}^{13,24)}$. On the other hand, there was a study showing no significant concordance difference between MZ and DZ twins ${ }^{25)}$. Several reports pointed out that concordance twin studies need to consider the differences in the mean gestational age, birth weight, and gender between MZ and DZ twins, as well as birth order and intrauterine environmental factors ${ }^{2,13,25)}$.

\section{Identified mutations of surfactant metabolism}

SP-B and SP-C contribute to the surface tension-lowering activity of the PS. SP-B and SP-C are encoded by a single gene, located on chromosomes 2 and 8, respectively ${ }^{26-28)}$. ABCA3, which is a transporter of phospholipid into lamellar bodies (LBs), the storage organelles for the surfactant complex, is critical for the proper formation of LBs and for surfactant function. Mutations in the genes encoding SP-B (SFTPB), SP-C (SFTPC), and $A B C A 3$ (ABCA3) disrupt surfactant function and cause respiratory distress in the newborn ${ }^{11,23,29)}$. Table 1 shows representative mutations of $S F T P B, S F T P C$, and $A B C A 3$.

\section{Hereditary SP-B deficiency}

SP-B deficiency was first described in two siblings with severe lung disease in the newborn period ${ }^{8)}$. Infants with hereditary SP-B deficiency, who are typically full-term, present severe respiratory failure shortly after birth, which is similar to RDS of preterm infants ${ }^{30)}$. The most common mutation, found in 60\%-70\% of the cases of SP-B deficiency ${ }^{31)}$, is a 1 base-pair (C) deletion and 3 base-pair (GAA) insertion, which is a net 2 base-pair insertion at codon 121 in exon 4 of SFTPB (termed 121ins2) ${ }^{32)}$. It causes a frame shift and premature termination signal of translation, which results in absence of mature SP-B production. Infants homozygous for this autosomal recessive loss-of-function mutation are refractory to surfactant replacement therapy, and the cases are mostly fatal without lung transplantation ${ }^{33)}$. The frequencies of 121 ins 2 are rare: $0.4 \%$ of a cohort in Missouri, 0.1\% in Norway, and $0 \%$ in Korea and South Africa, in a population-based study ${ }^{34)}$. Besides the 121ins2 mutation, more than 30 loss-of function mutations in SFTPB have been identified to date ${ }^{11,22,23,35-37)}$. Other loss-of-function mutations appear to be family specific and sometimes associated with the partial or transient deficiency of $\mathrm{SP}-\mathrm{B}$ that results in a more gradually progressive and prolonged survival $^{38,39)}$. 


\section{Mutations in SFTPC}

The SFTPC gene encodes SP-C, a hydrophobic protein like $\mathrm{SP}-\mathrm{B}$, which functions to lower the surface tension of the $\mathrm{PS}^{40)}$. The surfactant protein C precursor (proSP-C) is an essential endoplasmic reticulum (ER) membrane protein with an $\alpha$-helical transmembrane domain. Various mutations in the ER-luminal C-terminal domain of proSP-C have been reported ${ }^{411}$. Mutations in SFTPC are thought to result in the production of misfolded proSP-C molecules that accumulate within the alveolar type II cells and cause cellular injury. Contrary to SP-B, mutations in SFTPC penetrate variably, and its expression ranges from severe RDS of the newborn to chronic interstitial lung disease of the adult or even asymptomatic conditions ${ }^{9,42-44)}$. Presentation in fullterm infants in the newborn period is associated with signs and symptoms typical of RDS, and may be fatal in the neonatal period ${ }^{45}$. Over half of the mutations are thought to arise spontaneously and result in sporadic $\operatorname{cases}^{23}$. About 35 dominantly expressed mutations in SFTPC have been identified, where threonine substitution for isoleucine in codon 73 (I73T) is the most com$\operatorname{mon}^{43)}$.

\section{Mutations in $A B C A 3$}

Several mutations of $A B C A 3$ were first identified in 16 of 21 patients with severe neonatal surfactant deficiency ${ }^{10}$. Markedly abnormal LBs were observed by ultrastructural examination of lung tissue from four patients with different $A B C A 3$ mutations. The clinical manifestation and course of $A B C A 3$ mutations are variable: mutations in this gene can result in fatal surfactant deficiency in term newborn infants ${ }^{29)}$, which have similar clinical and radiologic findings to SP-B deficiencies, and chronic interstitial lung disease in older children ${ }^{46,47}$. More than 70 mutations have been reported, most of which are family specific ${ }^{233}$. The overall frequency of mutations and disease is unknown.

\section{Transcription factors that regulate the gene expression of surfactant proteins: mostly animal experimental studies}

A transcription factor is a protein that binds to specific DNA sequences to control transcription to messenger RNA. A number of transcription factors, including thyroid transcription factor-1 (TTF1; also known as NK2 homeobox 1 [Nkx2.1] or thyroid-specificenhancer-binding protein [T/EBP] ${ }^{48,49)}$, CCAAT enhancer binding protein- $\alpha(\mathrm{C} / \mathrm{EBP} \alpha)^{50)}$, and forkhead box A2 (Foxa2) ${ }^{511}$, have been

Table 1. Representative mutations of SFTPB, ABCA3, and SFTPC

\begin{tabular}{|c|c|c|c|c|c|}
\hline \multirow{2}{*}{ Gene } & \multicolumn{2}{|l|}{ Mutation } & \multicolumn{2}{|c|}{ Predicted result } & \multirow{2}{*}{-Reference } \\
\hline & Genetic change & Type & mRNA/protein & Clinical outcome & \\
\hline \multirow[t]{8}{*}{ SFTPB } & 1549C>GAA (121 ins2)* & & & & \\
\hline & $\begin{array}{l}\text { 1549C> GAA homozygote } \\
\text { (in exon 4) }\end{array}$ & Frameshift & $\begin{array}{l}\text { Complete absence of mRNA and } \\
\text { SP-B }\end{array}$ & $\begin{array}{l}\text { Fatal respiratory failure in early newborn } \\
\text { period }\end{array}$ & 32 \\
\hline & 1549C>GAA heterozygote & & & & \\
\hline & $\begin{array}{l}\text { 1549C>GAA/457delC } \\
\text { (in exon 4/exon 2) }\end{array}$ & Frameshift & Complete absence of SP-B & $\begin{array}{l}\text { Fatal respiratory failure in early newborn } \\
\text { period }\end{array}$ & 85 \\
\hline & $\begin{array}{l}1549 \mathrm{C}>\mathrm{GAA} / 4380 \mathrm{C}>\mathrm{T}(236 \mathrm{R}>\mathrm{C}) \\
\text { (in exon 4/exon 7) }\end{array}$ & Missense & $\begin{array}{l}\text { Near normal content of mRNA, a } \\
\text { low but detectable level of SP-B }\end{array}$ & $\begin{array}{l}\text { Rapidly severe respiratory distress and } \\
\text { persistent oxygen requirement (lethal) }\end{array}$ & 86 \\
\hline & $\begin{array}{l}2479 G>T(c .479 G>T \text { ) homozygote } \\
\text { (in exon 5) }\end{array}$ & $\begin{array}{l}\text { Splice (a frameshift and } \\
\text { a termination codon } \\
\text { in exon 7) }\end{array}$ & Reduced amount of mature SP-B & $\begin{array}{l}\text { Case 1: need lung transplantation } \\
\text { Case 2: persistent oxygen requirement }\end{array}$ & 38 \\
\hline & $\begin{array}{l}\text { c.673-1248del2959 homozygote } \\
\text { (in exon 7-8) }\end{array}$ & Deletion & & $\begin{array}{l}\text { Fatal respiratory failure in early newborn } \\
\text { period }\end{array}$ & 87 \\
\hline & $\begin{array}{l}\text { 2417G>A (G135S) heterozygote } \\
\text { (in exon 5) }\end{array}$ & Missense & Transient absence of SP-B & $\begin{array}{l}\text { Respiratory distress in early newborn } \\
\text { period } \rightarrow \text { continuous oxygen requirement }\end{array}$ & 39 \\
\hline \multirow[t]{3}{*}{$A B C A 3$} & $\begin{array}{l}\text { E292V (c.875A>T) heterozygote } \\
\text { (in exon 9) }\end{array}$ & $\begin{array}{l}\text { Missense (termination } \\
\text { codon in exon 33) }\end{array}$ & Defects in phosphocholine transport & Less severe (interstitial lung disease) & 46 \\
\hline & $\begin{array}{l}\text { L1580P }(4739 T>C) / 4552 \text { ins T } \\
\text { (in exon 31/exon 30) }\end{array}$ & Missense/frameshift & Trafficking defects & Rapidly fatal respiratory failure & 10,88 \\
\hline & $\begin{array}{l}\text { G1221S(3661G>A)/ L982P(2945T>C) } \\
\text { (in exon 24/exon 21) }\end{array}$ & Missense/missense & Trafficking defects & Rapidly fatal respiratory failure & 10,88 \\
\hline \multirow[t]{4}{*}{ SFTPC } & +128T>A heterozygote (in exon 5) & & Misfolding and trapping of proSP-C & Familial pulmonary fibrosis & 42 \\
\hline & $\begin{array}{l}\text { p.I73T }(218 \mathrm{~T}>\mathrm{C} \text { ) heterozygote } \\
\text { (in exon 3) }\end{array}$ & & Misfolding and trapping of proSP-C & $\begin{array}{l}\text { Familial interstitial lung disease, asym- } \\
\text { ptomatic parent of the patient }\end{array}$ & 43 \\
\hline & p.L188Q & & partially trafficked to lamellar bodies & Interstitial lung disease & 89,90 \\
\hline & p.P30L & & $\begin{array}{l}\text { Arrested proSP-C in the endoplas- } \\
\text { mic reticulum }\end{array}$ & Interstitial lung disease & 90 \\
\hline
\end{tabular}

SP-B, surfactant proteins B; proSP-C, surfactant protein $C$ precursor.

${ }^{*}$ The most common mutation of SFTPB; $60 \%-70 \%$ of the cases of SP-B deficiency. 
identified that influence lung formation and surfactant production as well as homeostasis in late gestation. TTF-1, C/EBP $\alpha$, and Foxa2 interact reciprocally to regulate transcriptional targets of surfactant synthesis and peripheral lung maturation ${ }^{50)}$.

TTF-1, encoded by NKX2-1, is expressed in the thyroid gland, brain, and lung ${ }^{48)}$. In the lung, it is an early marker of lung differentiation and an essential regulator for the expression of SP-A, SP-B, SP-C, and $A B C A 3^{49)}$. Mutations in NKX2-1 result in RDS and respiratory failure in newborn infants and in interstitial lung disease in older children ${ }^{36,49,52)}$.

$\mathrm{C} / \mathrm{EBP} \alpha$, a member of a family of basic leucine zipper transcription factors, plays an important role in the synthesis and metabolism of surfactant lipids and proteins. Deletion of the CEBPA gene causes the inhibition of lung epithelial cell proliferation and differentiation ${ }^{50)}$.

Deletion of FOXA2 inhibits branching morphogenesis and epithelial cell differentiation of the lung ${ }^{51)}$. Foxa2 modulates gene expression by interacting with other transcription factors. An animal study showed that the mammalian sterile 20-like kinase 1 and 2 (Mst1/2) regulated Foxa2, and might be crucial factors in surfactant homeostasis ${ }^{53)}$.

\section{Candidate genetic polymorphisms of SPs}

\section{SP-A}

Among the three forms of PS ${ }^{54)}$ (viz., intracellular and extracellular LBs, extracellular tubular myelin [TM], and surface monolayer), TM was absent in the lung of newborns who had died of $\mathrm{RDS}^{55)}$. Moreover, the expression of SP-A was very low ${ }^{56)}$. The levels of SP-A in tracheal aspirates, cord blood, and serum of newborn infants with RDS were lower than in infants without $\mathrm{RDS}^{57-60)}$. Owing to these significant findings and the important roles of SP-A in the pulmonary host defense mechanism and the formation of $\mathrm{TM}^{61-63)}$, the genes expressing SP-A have been thought to be strong candidates for susceptibility to RDS.

Two functional genes encoding SP-A (SFTPA1 and SFTPA2) are located on chromosome 10q22-q23 ${ }^{64)}$. Various single nucleotide polymorphisms (SNPs) have been discovered in coding regions and untranslated regions of SFTPA1 and SFTPA2 $2^{65-67)}$, and many association studies with RDS have been reported ${ }^{68-73)}$. Lee et $\mathrm{al}^{74)}$ and Kim et al. ${ }^{75)}$ have presented the distribution and frequency of SP-A alleles in Korean newborns.

The SP-A1 6A $\mathrm{A}^{2}, \mathrm{SP}-\mathrm{A}^{2} 1 \mathrm{~A}^{0}$ variant and SP-A1/SP-A2 6A $2 / 1 \mathrm{~A}^{0}$ haplotype have frequently been reported as being associated risk factors for the development of RDS, and the SP-A1 6A $\mathrm{A}^{3}$ variant as a protective factor for RDS, in Finnish and North American studies ${ }^{12,68-}$ ${ }^{70)}$. However, these association patterns were significantly different in a study of Korean preterm infants ${ }^{71)}$. The SP-A2 $1 \mathrm{~A}^{0}$ variant and
$1 \mathrm{~A}^{0} / 1 \mathrm{~A}^{0}$ genotype were associated with protection from RDS, whereas SP-A1 $6 \mathrm{~A}^{2}$ was not. The contrasting association of RDS with specific SP-A variants among different ethnic groups suggests that RDS is a multifactorial disease. In certain studies, associations between specific variants and RDS risk were confirmed under specific conditions or subgroups, such as infants born of twins or specific gestations, having the specific SP-B genotype or specific haplotypes of SP-A and SP-D ${ }^{69,72,73)}$. Although various association studies of SP-A genetic polymorphisms and RDS have been reported, the precise mechanism of the cause-and-effect relationship between specific polymorphisms and RDS has not been revealed up to now ${ }^{12)}$. Table 2 shows representative genetic polymorphisms of SPs associated with RDS.

\section{SP-B}

SP-B plays essential roles in forming LBs and maintaining the surface monolayer ${ }^{76}$. SFTPB has been thought to be an important candidate gene for RDS. Hereditary SP-B deficiency caused by mutations of SFTPB results in lethal neonatal respiratory disease. The reduction of SP-B concentration to $<25 \%$ of normal levels caused respiratory failure in adult mice ${ }^{77)}$. SP-B and SP-C levels of tracheal aspirate were correlated with surfactant function in premature infants ${ }^{78)}$. The SFTPB gene on chromosome 2p12-p11.2 is approximately $9.7 \mathrm{~kb}$ long, with 11 exons and 10 introns, including a large untranslated region ${ }^{26)}$, and is polymorphic ${ }^{79,80)}$. Hamvas et al. ${ }^{80)}$ reported 86 SFTPB polymorphic sites (9.8/1,000 base pairs of SFTPB reference sequence), including 81 SNPs and 5 small insertion/deletions. Several studies showed specific SNPs or length variation (insertion/deletion polymorphic changes) in intron 4 of SFTPB to be associated with RDS development ${ }^{25,79,81)}$.

\section{SP-C}

$\mathrm{SP}-\mathrm{C}$ is expressed as a proSP-C that matures to $\mathrm{SP}-\mathrm{C}$, containing only 35 amino acids. SFTPC is located on the short arm of chromosome $8(8 \mathrm{p} 23.1)^{27)}$. Mutations of SFTPB can disturb the proSP-C processing $^{28)}$. SP-C is thought to be a hydrophobic protein critical to lowering surface tension by enhancing the adsorption and spreading of surfactant phospholipids to the pulmonary surface monolayer; however, the exact functional roles of SP-C are currently not completely understood. Moreover, studies concerning the distribution of allelic variation in SFTPC and the associations with human disease are very rare. Lahti et al. ${ }^{82)}$ showed that SP-C polymorphisms were associated with RDS risk among infants born at $<28$ weeks of gestation.

\section{SP-D}

SP-D is an important component of the innate pulmonary immune system and, like SP-A, plays a role in PS homeostasis ${ }^{61,62)}$. The SFTPD gene, encoding for SP-D, is assigned to chromosome 10q22-q23 near SFTPA2 ${ }^{64)}$. Specific polymorphisms of SFTPD 
Table 2. Representative genetic polymorphisms of surfactant proteins associated with respiratory distress syndrome

\begin{tabular}{|c|c|c|c|c|}
\hline \multirow{2}{*}{ Gene } & \multicolumn{2}{|c|}{ Variants according to susceptibility } & \multirow{2}{*}{ Specific condition/subgroups } & \multirow{2}{*}{ Reference } \\
\hline & Risk & Protective & & \\
\hline \multirow[t]{6}{*}{ SFTPA } & $6 A^{2}, 6 A^{2} / 1 A^{0}$ & $6 A^{3}$ & Finnish & 68 \\
\hline & $6 A^{2}, 1 A^{0}$ & $6 A^{3}$ & SFTPB 131 Thr/Thr, GP<32 wk, Finnish & 69 \\
\hline & $6 A^{2}, 6 A^{2} / 1 A^{0}, 1 A^{0}$ & & Caucasian, African-American & 70 \\
\hline & $1 A^{1}$ & $1 A^{0}$ & Preterm infants, Korean & 71 \\
\hline & & $6 A^{2}, 6 A^{2} / 6 A^{2}, 6 A^{2} / 1 A^{0}$ & GP $32-36$ twins, Finnish & 72 \\
\hline & & $1 A^{1}$ & SFTPD DA160 A & 73 \\
\hline \multirow[t]{2}{*}{ SFTPB } & $131 \mathrm{Thr}$ & & First-born preterm twins, Finnish & 25 \\
\hline & Insertion/deletion of intron $4^{*}$ & & Caucasian, African-American & 79 \\
\hline SFTPC & g. $2772 G>A$ (exon 5) or p.186 Asn & & GP $<34$ wk, Finnish & 82 \\
\hline SFTPD & & rs1923537 G/G & $\mathrm{GP}<32$ wk, German & 84 \\
\hline
\end{tabular}

GP, gestational period.

*The first half of intron 4 of the SFTPB gene is a CA-repeat-rich region that contains 11 motifs.

Modified from Jo HS. Neonatal Med 2013;20:311- $7^{911}$.

influence the structure, function, and serum concentration of SP-

$\mathrm{D}^{21,83}$. Associations of protective haplotypes of SP-A/SP-D with RDS development ${ }^{73)}$ and specific genotypes of SP-D with the severity of $\mathrm{RDS}^{84)}$ have been reported.

\section{Conclusions}

Because RDS is thought to be a multifactorial and/or multigenetic disease, it is necessary to be well-informed of the genetic contributors for RDS before designing any studies to search for new factors associated with the disorder.

To date, the frequency of inherited mutations that result in defective surfactant metabolism has not been revealed in the Korean population. Although it seems to be rare, the clinical outcomes of such mutations are mostly fatal. Therefore, we need to investigate the possibility of these mutations and to try to diagnose for them using genetic sequencing in neonatal cases of RDS presenting with an unusual course of severe respiratory failure, especially those with a familial history.

Even though the direct association of genetic polymorphisms with the development of RDS has not been confirmed to date, there have been many meaningful association studies. Largescaled association studies are needed, considering the low penetrance of common genetic variants. The results of association studies can provide basic information for high-throughput genomic and proteomic researches and help to target specific therapies in the future.

\section{Conflict of interest}

No potential conflict of interest relevant to this article was reported.

\section{References}

1. Avery ME, Mead J. Surface properties in relation to atelectasis and hyaline membrane disease. AMA J Dis Child 1959;97(5 Part 1): 517-23.

2. Hallman M, Marttila R, Pertile R, Ojaniemi M, Haataja R. Genes and environment in common neonatal lung disease. Neonatology 2007;91:298-302.

3. Farrell PM, Wood RE. Epidemiology of hyaline membrane disease in the United States: analysis of national mortality statistics. Pediatrics 1976;58:167-76.

4. Bryan H, Hawrylyshyn P, Hogg-Johnson S, Inwood S, Finley A, D'Costa M, et al. Perinatal factors associated with the respiratory distress syndrome. Am J Obstet Gynecol 1990;162:476-81.

5. Fujikura T, Froehlich LA. The influence of race and other factors on pulmonary hyaline membranes: a report from the Collaborative Study of Cerebral Palsy. Am J Obstet Gynecol 1966;95:572-8.

6. Nagourney BA, Kramer MS, Klebanoff MA, Usher RH. Recurrent respiratory distress syndrome in successive preterm pregnancies. J Pediatr 1996;129:591-6.

7. Reed DM, Bakketeig LS, Nugent RP. The epidemiology of respiratory distress syndrome in Norway. Am J Epidemiol 1978;107:299-310.

8. Nogee LM, de Mello DE, Dehner LP, Colten HR. Brief report: deficiency of pulmonary surfactant protein B in congenital alveolar proteinosis. N Engl J Med 1993;328:406-10.

9. Nogee LM, Dunbar AE 3rd, Wert SE, Askin F, Hamvas A, Whitsett JA. A mutation in the surfactant protein $C$ gene associated with familial interstitial lung disease. N Engl J Med 2001;344:573-9.

10. Shulenin S, Nogee LM, Annilo T, Wert SE, Whitsett JA, Dean M. $\mathrm{ABCA} 3$ gene mutations in newborns with fatal surfactant deficiency. N Engl J Med 2004;350:1296-303.

11. Wert SE, Whitsett JA, Nogee LM. Genetic disorders of surfactant dysfunction. Pediatr Dev Pathol 2009;12:253-74.

12. Silveyra P, Floros J. Genetic variant associations of human SP- A and SP-D with acute and chronic lung injury. Front Biosci (Landmark Ed) 2012;17:407-29.

13. Hallman M, Haataja R. Surfactant protein polymorphisms and 
neonatal lung disease. Semin Perinatol 2006;30:350-61.

14. Ross S, Naeye RL. Racial and environmental influences on fetal lung maturation. Pediatrics 1981;68:790-5.

15. Hulsey TC, Alexander GR, Robillard PY, Annibale DJ, Keenan A. Hyaline membrane disease: the role of ethnicity and maternal risk characteristics. Am J Obstet Gynecol 1993;168:572-6.

16. Kavvadia V, Greenough A, Dimitriou G, Hooper R. Influence of ethnic origin on respiratory distress syndrome in very premature infants. Arch Dis Child Fetal Neonatal Ed 1998;78:F25-8.

17. Anadkat JS, Kuzniewicz MW, Chaudhari BP, Cole FS, Hamvas A. Increased risk for respiratory distress among white, male, late preterm and term infants. J Perinatol 2012;32:780-5.

18. Olowe SA, Akinkugbe A. Amniotic fluid lecithin/sphingomyelin ratio: comparison between an African and North American community. Pediatrics 1978;62:38-41.

19. Effect of antenatal dexamethasone administration on the prevention of respiratory distress syndrome. Am J Obstet Gynecol 1981; 141:276-87.

20. Richardson DK, Torday JS. Racial differences in predictive value of the lecithin/sphingomyelin ratio. Am J Obstet Gynecol 1994;170(5 Pt 1):1273-8.

21. Leth-Larsen R, Garred P, Jensenius H, Meschi J, Hartshorn K, Madsen $\mathrm{J}$, et al. A common polymorphism in the SFTPD gene influences assembly, function, and concentration of surfactant protein D. J Immunol 2005;174:1532-8.

22. Cole FS, Hamvas A, Nogee LM. Genetic disorders of neonatal respiratory function. Pediatr Res 2001;50:157-62.

23. Hamvas A, Cole FS, Nogee LM. Genetic disorders of surfactant proteins. Neonatology 2007;91:311-7.

24. van Sonderen L, Halsema EF, Spiering EJ, Koppe JG. Genetic influences in respiratory distress syndrome: a twin study. Semin Perinatol 2002;26:447-9.

25. Marttila R, Haataja R, Ramet M, Lofgren J, Hallman M. Surfactant protein $\mathrm{B}$ polymorphism and respiratory distress syndrome in premature twins. Hum Genet 2003;112:18-23.

26. Pilot-Matias TJ, Kister SE, Fox JL, Kropp K, Glasser SW, Whitsett JA. Structure and organization of the gene encoding human pulmonary surfactant proteolipid SP-B. DNA 1989;8:75-86.

27. Johansson J. Structure and properties of surfactant protein C. Biochim Biophys Acta 1998;1408:161-72.

28. Nogee LM. Genetics of the hydrophobic surfactant proteins. Biochim Biophys Acta 1998;1408:323-33.

29. Brasch F, Schimanski S, Muhlfeld C, Barlage S, Langmann T, Aslanidis $\mathrm{C}$, et al. Alteration of the pulmonary surfactant system in full-term infants with hereditary ABCA3 deficiency. Am J Respir Crit Care Med 2006;174:571-80.

30. Nogee LM. Surfactant protein-B deficiency. Chest 1997;111(6 Suppl): 129S-135S.

31. Hamvas A, Trusgnich M, Brice H, Baumgartner J, Hong Y, Nogee LM, et al. Population-based screening for rare mutations: highthroughput DNA extraction and molecular amplification from Guthrie cards. Pediatr Res 2001;50:666-8.

32. Nogee LM, Garnier G, Dietz HC, Singer L, Murphy AM, deMello $\mathrm{DE}$, et al. A mutation in the surfactant protein $\mathrm{B}$ gene responsible for fatal neonatal respiratory disease in multiple kindreds. J Clin Invest 1994;93:1860-3.

33. Hamvas A, Nogee LM, Mallory GB Jr, Spray TL, Huddleston CB, August A, et al. Lung transplantation for treatment of infants with surfactant protein B deficiency. J Pediatr 1997;130:231-9.

34. Garmany TH, Wambach JA, Heins HB, Watkins-Torry JM, Wegner DJ, Bennet K, et al. Population and disease-based prevalence of the common mutations associated with surfactant deficiency. Pediatr
Res 2008;63:645-9.

35. Nogee LM, Wert SE, Proffit SA, Hull WM, Whitsett JA. Allelic heterogeneity in hereditary surfactant protein B (SP-B) deficiency. Am J Respir Crit Care Med 2000;161(3 Pt 1):973-81.

36. Hamvas A. Current technology in the diagnosis of developmentally related lung disorders. Neonatology 2012;101:353-9.

37. Tredano M, Griese M, de Blic J, Lorant T, Houdayer C, Schumacher $\mathrm{S}$, et al. Analysis of 40 sporadic or familial neonatal and pediatric cases with severe unexplained respiratory distress: relationship to SFTPB. Am J Med Genet A 2003;119A:324-39.

38. Dunbar AE 3rd, Wert SE, Ikegami M, Whitsett JA, Hamvas A, White FV, et al. Prolonged survival in hereditary surfactant protein B (SPB) deficiency associated with a novel splicing mutation. Pediatr Res 2000;48:275-82.

39. Klein JM, Thompson MW, Snyder JM, George TN, Whitsett JA, Bell $\mathrm{EF}$, et al. Transient surfactant protein B deficiency in a term infant with severe respiratory failure. J Pediatr 1998;132:244-8.

40. Whitsett JA, Weaver TE. Hydrophobic surfactant proteins in lung function and disease. N Engl J Med 2002;347:2141-8.

41. Nerelius C, Martin E, Peng S, Gustafsson M, Nordling K, Weaver $\mathrm{T}$, et al. Mutations linked to interstitial lung disease can abrogate anti-amyloid function of prosurfactant protein C. Biochem J 2008; 416:201-9.

42. Thomas AQ, Lane K, Phillips J 3rd, Prince M, Markin C, Speer M, et al. Heterozygosity for a surfactant protein $\mathrm{C}$ gene mutation associated with usual interstitial pneumonitis and cellular nonspecific interstitial pneumonitis in one kindred. Am J Respir Crit Care Med 2002;165:1322-8.

43. Cameron HS, Somaschini M, Carrera P, Hamvas A, Whitsett JA, Wert SE, et al. A common mutation in the surfactant protein $C$ gene associated with lung disease. J Pediatr 2005;146:370-5.

44. Kropski JA, Lawson WE, Young LR, Blackwell TS. Genetic studies provide clues on the pathogenesis of idiopathic pulmonary fibrosis. Dis Model Mech 2013;6:9-17.

45. Soraisham AS, Tierney AJ, Amin HJ. Neonatal respiratory failure associated with mutation in the surfactant protein $\mathrm{C}$ gene. J Perinatol 2006;26:67-70.

46. Bullard JE, Wert SE, Whitsett JA, Dean M, Nogee LM. ABCA3 mutations associated with pediatric interstitial lung disease. Am J Respir Crit Care Med 2005;172:1026-31.

47. Doan ML, Guillerman RP, Dishop MK, Nogee LM, Langston C, Mallory GB, et al. Clinical, radiological and pathological features of ABCA3 mutations in children. Thorax 2008;63:366-73.

48. Boggaram V. Thyroid transcription factor-1 (TTF-1/Nkx2.1/TITF1) gene regulation in the lung. Clin Sci (Lond) 2009;116:27-35.

49. Whitsett JA, Wert SE, Trapnell BC. Genetic disorders influencing lung formation and function at birth. Hum Mol Genet 2004;13 Spec No 2:R207-15.

50. Martis PC, Whitsett JA, Xu Y, Perl AK, Wan H, Ikegami M. C/ EBPalpha is required for lung maturation at birth. Development 2006;133:1155-64.

51. Wan H, Dingle S, Xu Y, Besnard V, Kaestner KH, Ang SL, et al. Compensatory roles of Foxa1 and Foxa2 during lung morphogenesis. J Biol Chem 2005;280:13809-16.

52. Iwatani N, Mabe H, Devriendt K, Kodama M, Miike T. Deletion of NKX2.1 gene encoding thyroid transcription factor-1 in two siblings with hypothyroidism and respiratory failure. J Pediatr 2000;137:272-6.

53. Chung C, Kim T, Kim M, Kim M, Song H, Kim TS, et al. Hippo-Foxa2 signaling pathway plays a role in peripheral lung maturation and surfactant homeostasis. Proc Natl Acad Sci U S A 2013;110:7732-7.

54. Kikkawa Y. Morphology of alveolar lining layer. Anat Rec 1970; 
167:389-400.

55. deMello DE, Chi EY, Doo E, Lagunoff D. Absence of tubular myelin in lungs of infants dying with hyaline membrane disease. Am J Pathol 1987;127:131-9.

56. deMello DE, Phelps DS, Patel G, Floros J, Lagunoff D. Expression of the $35 \mathrm{kDa}$ and low molecular weight surfactant-associated proteins in the lungs of infants dying with respiratory distress syndrome. Am J Pathol 1989;134:1285-93.

57. Eguchi H, Koyama N, Tanaka T, Kamiya K, Ogawa Y. Surfactant apoprotein A (SP-A) in tracheal aspirates of newborn infants with RDS. Acta Paediatr Jpn 1991;33:649-54.

58. Stevens PA, Schadow B, Bartholain S, Segerer H, Obladen M. Surfactant protein A in the course of respiratory distress syndrome. Eur J Pediatr 1992;151:596-600.

59. Cho K, Matsuda T, Okajima S, Matsumoto Y, Sagawa T, Fujimoto $\mathrm{S}$, et al. Prediction of respiratory distress syndrome by the level of pulmonary surfactant protein A in cord blood sera. Biol Neonate 2000;77:83-7.

60. Kaneko K, Shimizu H, Arakawa H, Ogawa Y. Pulmonary surfactant protein A in sera for assessing neonatal lung maturation. Early Hum Dev 2001;62:11-21.

61. Crouch E, Wright JR. Surfactant proteins a and d and pulmonary host defense. Annu Rev Physiol 2001;63:521-54.

62. Hawgood S, Poulain FR. The pulmonary collectins and surfactant metabolism. Annu Rev Physiol 2001;63:495-519.

63. Wang G, Guo X, Diangelo S, Thomas NJ, Floros J. Humanized SFTPA1 and SFTPA2 transgenic mice reveal functional divergence of SP-A1 and SP-A2: formation of tubular myelin in vivo requires both gene products. J Biol Chem 2010;285:11998-2010.

64. Hoover RR, Floros J. Organization of the human SP-A and SP-D loci at 10q22-q23. Physical and radiation hybrid mapping reveal gene order and orientation. Am J Respir Cell Mol Biol 1998;18:353-62.

65. Krizkova L, Sakthivel R, Olowe SA, Rogan PK, Floros J. Human SP-A: genotype and single-strand conformation polymorphism analysis. Am J Physiol 1994;266(5 Pt 1):L519-27.

66. Floros J, DiAngelo S, Koptides M, Karinch AM, Rogan PK, Nielsen $\mathrm{H}$, et al. Human SP-A locus: allele frequencies and linkage disequilibrium between the two surfactant protein A genes. Am J Respir Cell Mol Biol 1996;15:489-98.

67. DiAngelo S, Lin Z, Wang G, Phillips S, Ramet M, Luo J, et al. Novel, non-radioactive, simple and multiplex PCR-cRFLP methods for genotyping human SP-A and SP-D marker alleles. Dis Markers 1999;15:269-81.

68. Rämet M, Haataja R, Marttila R, Floros J, Hallman M. Association between the surfactant protein A (SP-A) gene locus and respiratorydistress syndrome in the Finnish population. Am J Hum Genet 2000;66:1569-79.

69. Haataja R, Ramet M, Marttila R, Hallman M. Surfactant proteins A and $\mathrm{B}$ as interactive genetic determinants of neonatal respiratory distress syndrome. Hum Mol Genet 2000;9:2751-60.

70. Floros J, Fan R, Matthews A, DiAngelo S, Luo J, Nielsen H, et al. Family-based transmission disequilibrium test (TDT) and casecontrol association studies reveal surfactant protein A (SP-A) susceptibility alleles for respiratory distress syndrome (RDS) and possible race differences. Clin Genet 2001;60:178-87.

71. Jo HS, Cho SI, Chang YH, Kim BI, Choi JH. Surfactant protein A associated with respiratory distress syndrome in Korean preterm infants: evidence of ethnic difference. Neonatology 2013;103:44-7.

72. Marttila R, Haataja R, Ramet M, Pokela ML, Tammela 0, Hallman M. Surfactant protein A gene locus and respiratory distress syndrome in Finnish premature twin pairs. Ann Med 2003;35:344-52.

73. Thomas NJ, Fan R, Diangelo S, Hess JC, Floros J. Haplotypes of the surfactant protein genes A and D as susceptibility factors for the development of respiratory distress syndrome. Acta Paediatr 2007;96:985-9.

74. Lee KS, Kim YH, Suk JS, Ko JH, Yoo OJ, Lee IK, et al. Allele distribution and frequency of human surfactant protein-A1 in Korean neonates. J Korean Pediatr Soc 2002;45:1497-502.

75. Kim NC, Yoon HC, Suk JS, Ko JH, Yoo OJ, Lee IK, et al. Allele distribution and frequency of human surfactant protein-A2 in Korean neonates. J Korean Pediatr Soc 2003;46:340-4.

76. Whitsett JA, Nogee LM, Weaver TE, Horowitz AD. Human surfactant protein B: structure, function, regulation, and genetic disease. Physiol Rev 1995;75:749-57.

77. Melton KR, Nesslein LL, Ikegami M, Tichelaar JW, Clark JC, Whitsett JA, et al. SP-B deficiency causes respiratory failure in adult mice. Am J Physiol Lung Cell Mol Physiol 2003;285:L543-9.

78. Merrill JD, Ballard RA, Cnaan A, Hibbs AM, Godinez RI, Godinez $\mathrm{MH}$, et al. Dysfunction of pulmonary surfactant in chronically ventilated premature infants. Pediatr Res 2004;56:918-26.

79. Floros J, Veletza SV, Kotikalapudi P, Krizkova L, Karinch AM, Friedman C, et al. Dinucleotide repeats in the human surfactant protein-B gene and respiratory-distress syndrome. Biochem J 1995;305 ( Pt 2):583-90.

80. Hamvas A, Wegner DJ, Carlson CS, Bergmann KR, Trusgnich MA, Fulton L, et al. Comprehensive genetic variant discovery in the surfactant protein B gene. Pediatr Res 2007;62:170-5.

81. Marttila R, Haataja R, Guttentag S, Hallman M. Surfactant protein A and B genetic variants in respiratory distress syndrome in singletons and twins. Am J Respir Crit Care Med 2003;168:1216-22.

82. Lahti M, Marttila R, Hallman M. Surfactant protein C gene variation in the Finnish population - association with perinatal respiratory disease. Eur J Hum Genet 2004;12:312-20.

83. Sorensen GL, Husby S, Holmskov U. Surfactant protein A and surfactant protein D variation in pulmonary disease. Immunobiology 2007;212:381-416.

84. Hilgendorff A, Heidinger K, Bohnert A, Kleinsteiber A, Konig IR, Ziegler A, et al. Association of polymorphisms in the human surfactant protein-D (SFTPD) gene and postnatal pulmonary adaptation in the preterm infant. Acta Paediatr 2009;98:112-7.

85. Tredano M, van Elburg RM, Kaspers AG, Zimmermann LJ, Houdayer C, Aymard P, et al. Compound SFTPB 1549C-->GAA (121ins2) and 457delC heterozygosity in severe congenital lung disease and surfactant protein B (SP-B) deficiency. Hum Mutat 1999;14:502-9.

86. Ballard PL, Nogee LM, Beers MF, Ballard RA, Planer BC, Polk L, et al. Partial deficiency of surfactant protein B in an infant with chronic lung disease. Pediatrics 1995;96:1046-52.

87. Schuerman FA, Griese M, Gille JP, Brasch F, Noorduyn LA, van Kaam AH. Surfactant protein B deficiency caused by a novel mutation involving multiple exons of the SP-B gene. Eur J Med Res 2008;13:281-6.

88. Matsumura Y, Ban N, Ueda K, Inagaki N. Characterization and classification of ATP-binding cassette transporter ABCA3 mutants in fatal surfactant deficiency. J Biol Chem 2006;281:34503-14.

89. Johansson H, Nordling K, Weaver TE, Johansson J. The Brichos domain-containing C-terminal part of pro-surfactant protein $\mathrm{C}$ binds to an unfolded poly-val transmembrane segment. J Biol Chem 2006;281:21032-9.

90. Thurm T, Kaltenborn E, Kern S, Griese M, Zarbock R. SFTPC mutations cause SP-C degradation and aggregate formation without increasing ER stress. Eur J Clin Invest 2013;43:791-800.

91. Jo HS. Association between respiratory disorders and candidate genes in Korean newborn infants. Neonatal Med 2013;20:311-7. 